\title{
BMJ Open Determinants of immunological recovery following HAART among severely immunosuppressed patients at enrolment to care in Northern Ethiopia: a retrospective study
}

\author{
Abraham Aregay Desta (D) , ${ }^{1}$ Kibriti Mehari Kidane, ${ }^{2}$ Yemane Weldu Bahta, ${ }^{3}$ \\ Kiros Fenta Ajemu, ${ }^{2}$ Ataklti Gebretsadik Woldegebriel, ${ }^{2}$ Asfawosen Aregay Berhe, ${ }^{2}$ \\ Nega Mamo Bezabih, ${ }^{2}$ Awtachew Berhe Woldu, ${ }^{4}$ \\ Tewolde Wubayehu Woldearegay (1) ${ }^{2}$
}

To cite: Desta AA, Kidane KM, Bahta YW, et al. Determinants of immunological recovery following HAART among severely immunosuppressed patients at enrolment to care in Northern Ethiopia: a retrospective study. BMJ Open 2020;10:e038741. doi:10.1136/ bmjopen-2020-038741

- Prepublication history for this paper is available online. To view these files, please visit the journal online (http://dx.doi. org/10.1136/bmjopen-2020 038741).

Received 26 March 2020 Revised 10 June 2020 Accepted 02 July 2020
Check for updates

(c) Author(s) (or their employer(s)) 2020. Re-use permitted under CC BY-NC. No commercial re-use. See rights and permissions. Published by BMJ.

For numbered affiliations see end of article.

Correspondence to Abraham Aregay Desta; abaregaydesta@gmail.com

\section{ABSTRACT}

Objective This study aimed to identify determinants of immunological recovery following highly active antiretroviral therapy (HAART) among severely immunosuppressed patients at enrolment to care in Northern Ethiopia.

Methods A retrospective study.

Setting The study was done in Tigray Region, Northern Ethiopia.

Participants The study was done among severely immunosuppressed ( $<200 \mathrm{CD} 4 \mathrm{cells} / \mathrm{mm}^{3}$ ) individuals at initial enrolment to care and whose samples were sent for viral load determination from April 2015 to March 2019 in Tigray Health Research Institute.

Main outcomes The main outcome variable was immunological recovery, modelled using binary logistic regression.

Results Among the 9687 patients with severe immunosuppression at enrolment, 2746 (28.35\%, 95\% Cl $27.45 \%$ to $29.26 \%$ ) had immunological recovery following HAART for at least 6 months. Male gender (adjusted OR $(A O R)=0.50, p<0.001)$, age 20-34 years old $(A 0 R=0.33$, $p<0.001)$, age $\geq 50$ years old $(A 0 R=0.26, p<0.001)$, WHO clinical stage III $(0 R=0.68, p=0.036)$ and viral nonsuppression $(A O R=0.38, p<0.001)$ were strong predictors of immunological failure.

Conclusions Immunological recovery following HAART was low among severely immunosuppressed individuals at enrolment to care. Gender, age, WHO stage III and viral non-suppression were determinants of immunological recovery. Male patients, adolescents and virally nonsuppressed patients should be identified as groups at higher risk for immunological failure. Therefore, greater support and intensive counselling should be prioritised among adolescents, men and virally non-suppressed patients for better immunological recovery.

\section{INTRODUCTION}

HIV infects CD4+ T cells, replicates in these immune cells and gradually depletes these

\section{Strengths and limitations of this study}

- The study was done on a relatively higher sample size, which can be generalised to the national level.

- The study was done using routinely collected public health programme data which can reflect the outcome and effectiveness of current antiretroviral therapy (ART) in severely immunosuppressed patients.

- Appropriate statistical methods were used to present the findings of the study.

- There were no data available when baseline and recent CD4 T cell counts were determined and hence the time of immunological recovery is not known.

Due to the nature of the secondary data, the analysis misses some important variables, such as the existence of coinfection, drug side effects during followup, body mass index and grade of ART experience among HIV-infected patients.

immune cells, mainly CD4 lymphocytes, which are key in cell-mediated immune response, thereby contributing to poor humoral response against invading pathogens. ${ }^{1-4}$ After progressive depletion of $\mathrm{CD} 4+\mathrm{T}$ cells, the risk of opportunistic infections increases. Nevertheless, initiating antiretroviral therapy (ART) can help achieve suppression of viral replication, leading to an increase in $\mathrm{CD} 4+\mathrm{T}$ cell counts and restoring the body's capability to fight against opportunistic infections. ${ }^{15-9}$ This results in immune function recovery, accompanied by a dramatic decrement in morbidity and AIDS-related mortality. ${ }^{10} 11$ Globally, 20.9 million HIV-infected people were estimated to have received ART by June $2017 .^{12}$ 
The WHO recommends (as of 2015) that HIVinfected adults should receive ART right away irrespective of their CD4 count. ${ }^{13}$ After commencing ART, the expected outcome is either immunological recovery or failure. Immunological failure is defined as a CD4 count at or below 250 cells $/ \mathrm{mm}^{3}$ following clinical failure or persistent CD4 level below 100 cells $/ \mathrm{mm}^{3}$ in adults and adolescents. ${ }^{14}$ The minimum normal CD4 count for the general adult population is 500 cells $/ \mathrm{mm}^{3}$, and attaining this level after initiating ART is defined as immunological recovery. ${ }^{1415}$

There are a variety of factors that could influence the CD4 cell count of human beings. Studies have reported that individuals who start ART at a higher CD4 count ( $\geq 300$ cells $/ \mathrm{mm}^{3}$ ) have their CD4 cell count return to nearly normal or normal $\left(\geq 500\right.$ cells $\left./ \mathrm{mm}^{3}\right)$ than those who start at a lower baseline $\left(\leq 200\right.$ cells $\left./ \mathrm{mm}^{3}\right) \cdot{ }^{1416}$ Other different studies have also shown that poor immunological recovery and survival were observed in patients who initiated ART at low CD4 counts. ${ }^{17-19}$ Moreover, patients with poor immune recovery have shown to have a higher risk of developing both AIDS-related and non-AIDSrelated clinical events. ${ }^{14}$ Similar studies have also shown a link between viral suppression and improved immune response while on ART. ${ }^{20-22}$ On the other hand, there is evidence that older people have poorer response to ART treatment. $^{23} 24$

Despite ART coverage expanding dramatically in Ethiopia, nothing is known about the determinants of immunological recovery. However, immunological failure was considered as a proxy marker for virological failure. ${ }^{25}{ }^{26}$ Thus, it influences the performance of the virological suppression goal of the Joint United Nations Programme on HIV/AIDS third 90-90-90 target,${ }^{27}$ which aims to achieve $90 \%$ virological success in patients on ART.

This study is part of a previously published study, the results of which have not been presented elsewhere. ${ }^{28}$ None of the previously published studies identified the determinants of immunological recovery following highly active antiretroviral therapy (HAART) among severely immunosuppressed individuals at enrolment to care in Tigray Region. ${ }^{28-30}$ Hence, it is important to identify determinants of immunological recovery among patients with $<200 \mathrm{CD} 4$ cells $/ \mathrm{mm}^{3}$ at enrolment to enhance immunological recovery and thereby survival. Therefore, this study aimed to identify determinants of immunological recovery following HAART among severely immunosuppressed patients at enrolment in Northern Ethiopia. This study will aid programme experts, leaders and clinicians in Ethiopia and other resource-limited settings in identifying determinants of immunological recovery following HAART among severely immunosuppressed patients at enrolment so as to reduce complications and enhance management of these patients.

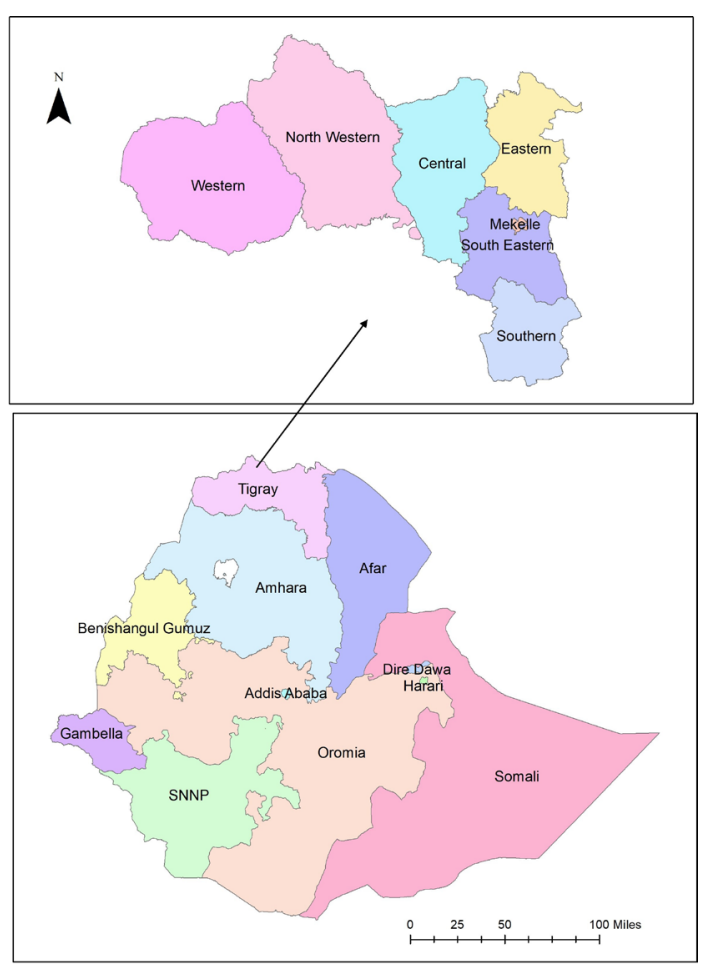

Figure 1 Map of the study area: Tigray regional state, Northern Ethiopia. SNNP, Southern Nations, Nationalities, and Peoples

\section{METHODS}

\section{Study setting}

The study was done in Tigray Region, which is the sixth largest by surface area and the fourth most populous of the nine regional states of Ethiopia ${ }^{31}$ (see figure 1).

\section{Study design}

A retrospective analysis study design was used.

\section{Participants}

The participants of this study were severely immunosuppressed patients at enrolment and on HAART for at least 6 months and whose samples were sent to Tigray Health Research Institute (THRI) for viral load (VL) determination through standard sample transportation technique from April 2015 to March 2019. THRI serves as a regional reference laboratory and is the only centre for VL determination in Tigray Region and for some parts of Afar Region. The study was done among 9687 patients with complete data on demographics, clinical and immunological characteristics, and VL in the THRI database.

\section{Eligibility criteria}

\section{Inclusion criteria}

- Patients enrolled in ART care for at least 6 months.

Exclusion criteria

- Individuals with $\geq 200 \mathrm{CD} 4$ cells $/ \mathrm{mm}^{3}$ at enrolment to care.

- Subjects younger than 15 years. 


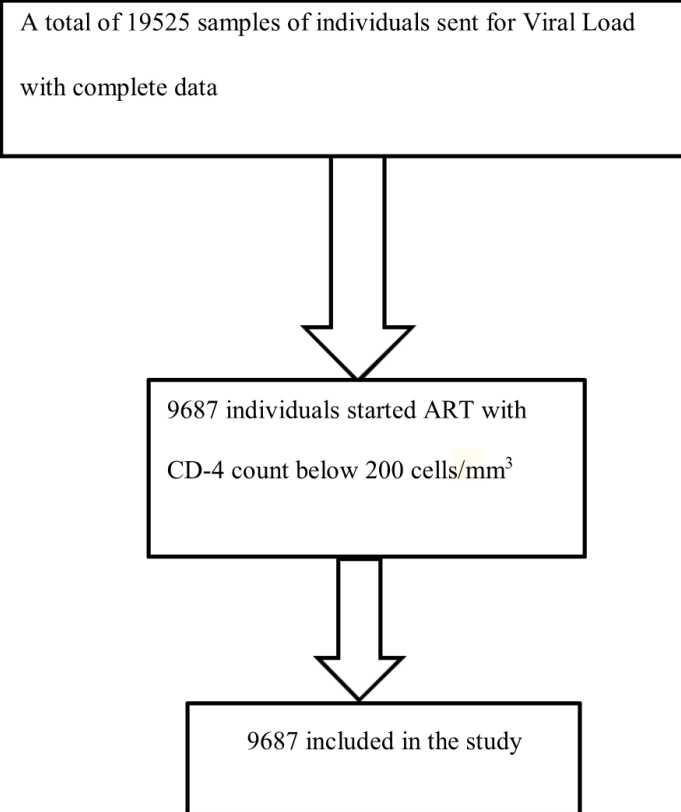

Figure 2 Schematic presentation of the sampling procedure. ART, antiretroviral therapy.

\section{Sampling procedure}

To come up with the sample, all records of HIV in the THRI database with complete information were extracted. All individuals who fulfil the eligibility criteria were included in the study (see figure 2).

\section{Data collection tools and procedures}

All data in the database were exported to Microsoft Excel 2013 and data verification and filtration were done before exporting to STATA V.14.0. Laboratory testing methods included the following: RNA extraction and plasma VL determination were done from samples of plasma from each patient sent to THRI. HIV-1 RNA was extracted from $0.2 \mathrm{~mL}$ of plasma using Abbott m2000sp automated sample preparation system (Abbott Molecular, USA). Extracted RNA was measured using Abbott m2000rt quantitative real-time HIV-1 assay (Abbott Molecular) with HIV-1 RNA detection level of 40-10 million copies/ $\mathrm{mL}$ based on the manufacturer's procedures. The CD4 count was determined at respective healthcare facilities using FACSCount, and baseline and recent CD4 counts of each patient were sent to THRI through the VL standard referral form.

\section{Patient and public involvement}

The study involved immunosuppressed patients at enrolment following HAART in Tigray healthcare facilities.

\section{Operational definitions}

- Immunological recovery: patients enrolled to care whose CD 4 count was below 200 cells $/ \mathrm{mm}^{3}$ at baseline and who have achieved $\geq 500 \mathrm{CD} 4$ cells $/ \mathrm{mm}^{3}$ in recent CD4 measurement at the continuum of ART care.

- Severely immunosuppressed: patients with <200 CD4 cells $/ \mathrm{mm}^{3}$ at enrolment to care.
- Viral suppression: patients whose VL is $<1000$ copies of viral RNA $/ \mathrm{mm}^{3}$.

- Good adherence: self-reported drug adherence of $95 \%$ or $\leq 2$ missed drug doses of 30 doses or $\leq 3$ missed drug doses of 60 doses at recent contact.

- Fair adherence: self-reported drug adherence of $85 \%-94 \%$ or $3-5$ missed drug doses of 30 doses or 3-9 missed drug doses of 60 doses at recent contact.

- Poor adherence. self-reported drug adherence of $<85 \%$ or $\geq 6$ doses of missed ART drug doses of 30 doses or $>9$ doses missed ART drug doses of 60 doses at recent contact.

- Patients: individuals on HAART at age 15 years and older.

\section{Data quality assurance}

Data consistency and completeness were checked using Microsoft Excel 2013. High and low positive controls were checked during VL determination in THRI. CD4 count quality control measures were done based on low, medium and high controls to evaluate run validity in each laboratory where CD4 count was done.

\section{Data management and analysis}

Analysis was done using STATA V.14.0 to estimate the proportion and determinants of immunological recovery among patients with severe immunosuppression at baseline (at enrolment to care) following HAART. The variable 'viral suppression' was categorised based on WHO categorisation for low-income and middle-income countries (LMICs). Missed values were filtered and excluded for all variables; hence, there was no issue on missing values in the final data set. The outcome variable was dichotomised ( $1=$ immunological recovery and $0=\mathrm{immu}-$ nological non-recovery). Descriptive analysis was done for demographic, clinical, virological and immunological characteristics. Cross tabulations were done among the different variables with the outcome variable.

The proportion of patients who had immunological recovery was obtained by dividing the total number of patients with severe immunosuppression who have achieved immunological recovery by the total number of patients with severe immunosuppression at baseline. The proportion of immunological recovery was further evaluated by age group, sex, adherence level, pregnancy status, breastfeeding status, WHO staging, regimen type, treatment line, reason for VL test, health facility ownership and health facility level.

Statistical significance was considered at $\mathrm{p}<0.05$ (twosided) in all tests. Robust SE type was used in the analysis of bivariate and multivariate logistic regression. To identify determinant factors associated with immunological recovery, bivariate analysis was first conducted to identify the strength of association with immunological recovery at crude level. Crude OR was calculated at the bivariate logistic regression. All significant variables in bivariate analysis were entered into the multivariate analysis. Multivariate binary logistic regression was used to identify 
Table 1 Background and clinical characteristics of severely immunosuppressed patients in Northern Ethiopia, $\mathrm{N}=9687$

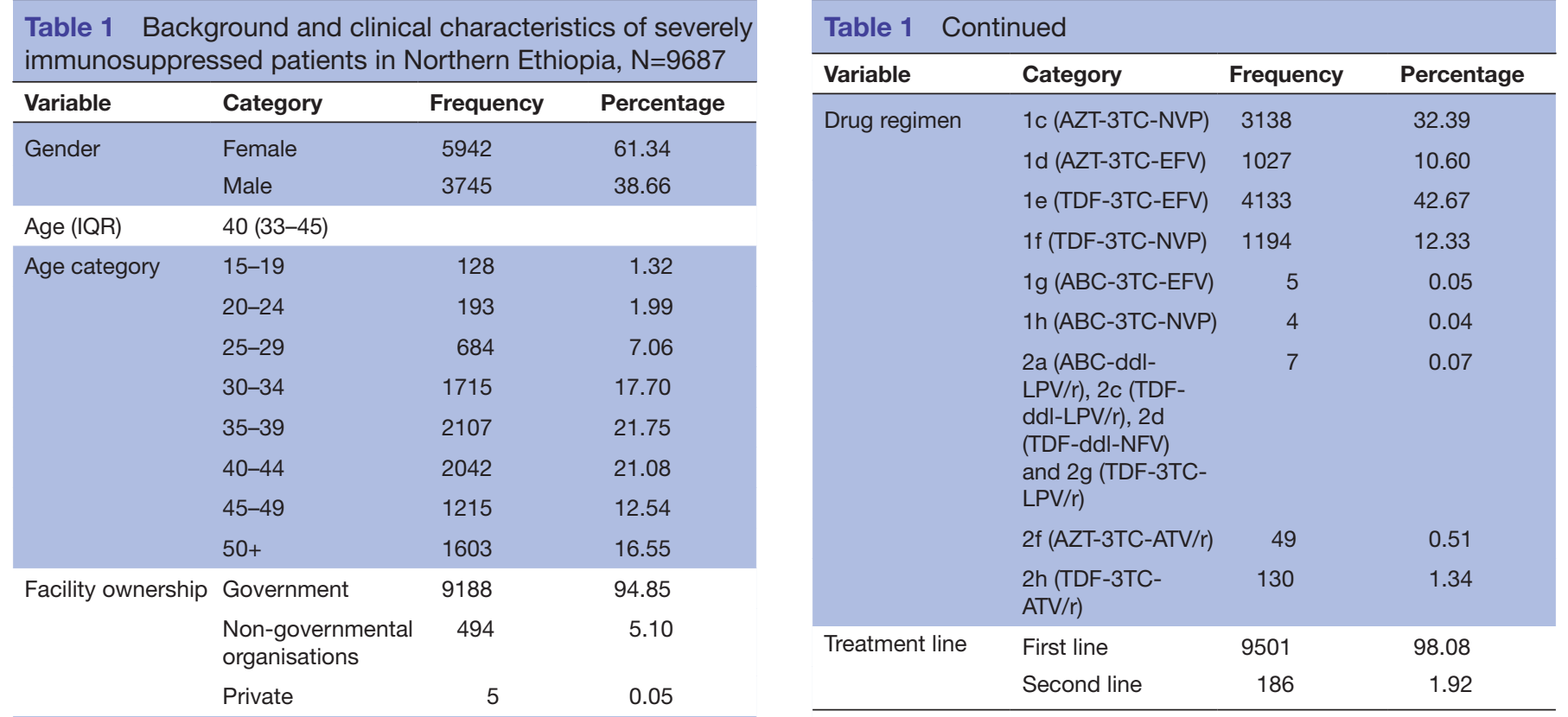

\begin{tabular}{|c|c|c|c|}
\hline \multirow[t]{6}{*}{ Facility type } & Clinic & 11 & 0.11 \\
\hline & Health centre & 2273 & 23.46 \\
\hline & Primary hospital & 996 & 10.28 \\
\hline & General hospital & 5389 & 55.63 \\
\hline & Referral hospital & 857 & 8.85 \\
\hline & Other & 161 & 1.66 \\
\hline \multirow{2}{*}{$\begin{array}{l}\text { Service provided } \\
\text { in a military } \\
\text { facility }\end{array}$} & No & 9328 & 96.29 \\
\hline & Yes & 359 & 3.71 \\
\hline \multirow[t]{2}{*}{ Pregnant mother } & No & 5908 & 99.43 \\
\hline & Yes & 34 & 0.57 \\
\hline \multirow[t]{2}{*}{ Lactating mother } & No & 5864 & 98.69 \\
\hline & Yes & 78 & 1.31 \\
\hline \multirow[t]{4}{*}{ WHO stage } & 1 & 8750 & 90.33 \\
\hline & ॥ & 372 & 3.84 \\
\hline & III & 248 & 2.56 \\
\hline & IV & 317 & 3.27 \\
\hline \multirow[t]{3}{*}{ Adherence } & Poor & 164 & $1.6 \mathrm{~s}$ \\
\hline & Fair & 392 & 4.05 \\
\hline & Good & 9131 & 94.26 \\
\hline \multirow[t]{6}{*}{ Viral test reason } & Routine first VL & 5790 & 59.77 \\
\hline & Routine annual VL & 3063 & 31.62 \\
\hline & $\begin{array}{l}\text { Suspected clinical } \\
\text { ART failure }\end{array}$ & 26 & 0.27 \\
\hline & $\begin{array}{l}\text { Suspected } \\
\text { immunological } \\
\text { ART failure }\end{array}$ & 62 & 0.6 \\
\hline & $\begin{array}{l}\text { Suspected ART } \\
\text { failure on initial VL }\end{array}$ & 586 & 6.05 \\
\hline & $\begin{array}{l}\text { Not indicated in } \\
\text { the form }\end{array}$ & 160 & 1.65 \\
\hline \multirow[t]{2}{*}{ Recent VL status } & Suppressed & 6950 & 71.75 \\
\hline & Non-suppressed & 2737 & 28.25 \\
\hline
\end{tabular}

Continued
ABC, abacavir; ART, antiretroviral therapy; ATV/r, atazanavir/ritonavir; AZT, azidothymidine; ddl, didanosine; EFV, efavirenz; LPV/r, lopinavir/ritonavir; NFV, nelfinavir; NVP, nevirapine; 3TC, lamivudine; TDF, tenofovir disoproxil fumarate; VL, viral load.

factors independently associated with immunological recovery at adjusted level. As pregnancy and breastfeeding status apply to women, both variables were excluded from the final statistical modelling. Collinearity was omitted in statistical modelling of immunological recovery. Model adequacy was checked by Hosmer-Lemeshew test.

\section{RESULTS}

\section{Background characteristics}

Among the 9687 study subjects, about $61.34 \%$ were women. The median age of the patients was 40 (IQR 33-45). The age of most patients lies in the 35-39 and $40-44$ years age groups, accounting for $21.75 \%$ and $21.08 \%$, respectively. Around $95 \%$ of the patients were enrolled in governmental healthcare facilities.

Among the 5908 female patients, $34(0.57 \%)$ were pregnant and $78(1.31 \%)$ were lactating mothers. With regard to WHO staging, $90.33 \%, 3.84 \%, 2.56 \%$ and $3.27 \%$ of the patients were in stage I, II, III and IV, respectively. Even though $94.26 \%$ of the patients had good adherence, about $4.05 \%$ and $1.69 \%$ had fair and poor adherence, respectively (table 1 ).

\section{Determinants of immunological recovery}

Out of the 9687 patients with severe immunosuppression, only 2746 (28.35\%, 95\% CI $27.45 \%$ to $29.26 \%)$ had immunological recovery $\left(\geq 500\right.$ cells $\left./ \mathrm{mm}^{3}\right)$ after receiving ART for at least 6 months. Many variables were associated with immunological recovery in the bivariate analyses, including gender, age, patients enrolled in a military facility, WHO stage II and III, good adherence, suspected clinical ART failure, suspected immunological 
Table 2 Bivariate analysis of variables associated with immunological recovery among severely immunosuppressed adolescent and adult patients in Northern Ethiopia, $\mathrm{N}=9687$

\begin{tabular}{|c|c|c|c|c|c|}
\hline \multirow[b]{2}{*}{ Variable } & \multirow[b]{2}{*}{ Category } & \multicolumn{2}{|c|}{ Immunological recovery } & \multirow[b]{2}{*}{ COR $(95 \% \mathrm{CI})$} & \multirow[b]{2}{*}{$P$ value } \\
\hline & & No, n (\%) & Yes, n (\%) & & \\
\hline \multirow[t]{2}{*}{ Gender } & Female & $3906(56.27)$ & $2036(74.14)$ & 1 (ref) & \\
\hline & Male & 3035 (43.73) & $710(25.86)$ & $0.45(0.41$ to 0.49$)$ & $<0.001$ \\
\hline \multirow[t]{4}{*}{ Age category } & $15-19$ & $67(0.97)$ & $61(2.22)$ & 1 (ref) & \\
\hline & 20-34 & $1781(25.66)$ & $811(29.53)$ & $0.50(0.35$ to 0.71$)$ & $<0.001$ \\
\hline & $35-49$ & $3893(56.09)$ & $1471(53.57)$ & $0.42(0.29$ to 0.59$)$ & $<0.001$ \\
\hline & $50+$ & $1200(17.29)$ & $403(14.68)$ & $0.37(0.26$ to 0.53$)$ & $<0.001$ \\
\hline \multirow[t]{3}{*}{ Facility ownership } & Government & $6587(94.90)$ & 2601 (94.72) & 1 (ref) & \\
\hline & Non-governmental organisations & $350(5.04)$ & $144(5.24)$ & $1.04(0.85$ to 1.27$)$ & 0.686 \\
\hline & Private & $4(0.06)$ & $1(0.04)$ & $0.63(0.07$ to 5.67$)$ & 0.683 \\
\hline \multirow[t]{6}{*}{ Facility type } & Clinic & $7(0.10)$ & $4(0.15)$ & 1 (ref) & \\
\hline & Health centre & $1765(25.43)$ & $508(18.50)$ & $0.50(0.15$ to 1.73$)$ & 0.275 \\
\hline & Primary hospital & $776(11.18)$ & $220(8.01)$ & $0.50(0.14$ to 1.71$)$ & 0.267 \\
\hline & General hospital & $3614(52.07)$ & $1775(64.64)$ & 0.86 (0.25 to 2.94$)$ & 0.809 \\
\hline & Referral hospital & $663(9.55)$ & $194(7.06)$ & 0.51 (0.15 to 1.77$)$ & 0.290 \\
\hline & Other & $116(1.67)$ & $45(1.64)$ & 0.68 (0.19 to 2.43 ) & 0.552 \\
\hline \multirow{2}{*}{$\begin{array}{l}\text { Service provided in a military } \\
\text { facility }\end{array}$} & No & $6653(95.85)$ & $2675(97.41)$ & 1 (ref) & \\
\hline & Yes & $288(4.15)$ & $71(2.59)$ & $0.61(0.47$ to 0.80$)$ & $<0.001$ \\
\hline \multirow[t]{2}{*}{ Pregnant mother } & No & 3886 (99.49) & 2022 (99.31) & 1 (ref) & \\
\hline & Yes & $20(0.51)$ & $14(0.69)$ & 1.35 (0.68 to 2.67$)$ & 0.396 \\
\hline \multirow[t]{2}{*}{ Lactating mother } & No & $3860(98.82)$ & $2004(98.43)$ & 1 (ref) & \\
\hline & Yes & $46(1.18)$ & $32(1.57)$ & 1.34 (0.85 to 2.11$)$ & 0.207 \\
\hline \multirow[t]{4}{*}{ WHO stage } & I & 6228 (89.73) & 2522 (91.84) & 1 (ref) & \\
\hline & II & $286(4.12)$ & $86(3.13)$ & $0.74(0.58$ to 0.95$)$ & $<0.001$ \\
\hline & III & 207 (2.98) & $41(1.49)$ & $0.49(0.35$ to 0.69$)$ & $<0.001$ \\
\hline & IV & $220(3.17)$ & $97(3.53)$ & 1.09 (0.85 to 1.39$)$ & 0.493 \\
\hline \multirow[t]{3}{*}{ Adherence } & Poor & $132(1.90)$ & $32(1.17)$ & 1 (ref) & \\
\hline & Fair & $333(4.80)$ & $59(2.15)$ & $0.73(0.45$ to 1.18$)$ & 0.196 \\
\hline & Good & $6476(93.30)$ & 2655 (96.69) & 1.69 (1.15 to 2.49$)$ & 0.008 \\
\hline \multirow[t]{6}{*}{ Viral test reason } & Routine first VL & 4094 (58.98) & $1696(61.76)$ & 1 (ref) & \\
\hline & Routine annual VL & 2127 (30.64) & 936 (34.09) & 1.06 (0.97 to 1.17$)$ & 0.215 \\
\hline & Suspected clinical ART failure & $25(0.36)$ & $1(0.0 .04)$ & $0.10(0.01$ to 0.71$)$ & 0.022 \\
\hline & $\begin{array}{l}\text { Suspected immunological ART } \\
\text { failure }\end{array}$ & $59(0.85)$ & $3(0.11)$ & 0.12 (0.04 to 0.39$)$ & $<0.001$ \\
\hline & $\begin{array}{l}\text { Suspected ART failure on initial } \\
\text { VL }\end{array}$ & $523(7.53)$ & $63(2.29)$ & $0.29(0.22$ to 0.38$)$ & $<0.001$ \\
\hline & Not indicated in the form & $113(1.63)$ & $47(1.71)$ & $1.00(0.71$ to 1.42$)$ & 0.982 \\
\hline \multirow[t]{2}{*}{ Recent VL status } & Suppressed & $4610(66.42)$ & $2340(85.21)$ & 1 (ref) & \\
\hline & Non-suppressed & 2331 (33.58) & $406(14.79)$ & $0.34(0.31$ to 0.39$)$ & $<0.001$ \\
\hline \multirow[t]{9}{*}{ Drug regimen } & 1c (AZT-3TC-NVP) & 2033 (29.29) & $1105(40.24)$ & 1 (ref) & \\
\hline & 1d (AZT-3TC-EFV) & $722(10.40)$ & $305(11.11)$ & 0.78 (0.67 to 0.91$)$ & 0.001 \\
\hline & 1e (TDF-3TC-EFV) & $3223(46.43)$ & $910(33.14)$ & $0.52(0.47$ to 0.58$)$ & $<0.001$ \\
\hline & $1 \mathrm{f}$ (TDF-3TC-NVP) & 795 (11.45) & $399(14.53)$ & $0.92(0.80$ to 1.06$)$ & 0.267 \\
\hline & $1 \mathrm{~g}(\mathrm{ABC}-3 \mathrm{TC}-\mathrm{EFV})$ & $4(0.06)$ & $1(0.04)$ & 0.46 (0.05 to 4.12$)$ & 0.488 \\
\hline & 1h (ABC-3TC-NVP) & $3(0.04)$ & $1(0.04)$ & 0.61 (0.06 to 5.90$)$ & 0.672 \\
\hline & $\begin{array}{l}\text { 2a (ABC-ddl-LPV/r), 2c (TDF-ddl- } \\
\text { LPV/r), 2d (TDF-ddl-NFV) and } 2 \mathrm{~g} \\
\text { (TDF-3TC-LPV/r) }\end{array}$ & $5(0.07)$ & $2(0.07)$ & $0.74(0.14$ to 3.80$)$ & 0.714 \\
\hline & $2 f(A Z T-3 T C-A T V / r)$ & $43(0.62)$ & $6(0.22)$ & $0.26(0.11$ to 0.61$)$ & 0.002 \\
\hline & 2h (TDF-3TC-ATV/r) & $113(1.63)$ & $17(0.62)$ & $0.28(0.17$ to 0.46$)$ & $<0.001$ \\
\hline
\end{tabular}


Table 2 Continued

\begin{tabular}{|c|c|c|c|c|c|}
\hline \multirow[b]{2}{*}{ Variable } & \multirow[b]{2}{*}{ Category } & \multicolumn{2}{|c|}{ Immunological recovery } & \multirow[b]{2}{*}{ COR $(95 \% \mathrm{Cl})$} & \multirow[b]{2}{*}{$P$ value } \\
\hline & & No, n (\%) & Yes, n (\%) & & \\
\hline Treatment line & First line & $6780(97.68)$ & 2721 (99.09) & 1 (ref) & \\
\hline
\end{tabular}

ABC, abacavir; ART, antiretroviral therapy; ATV/r, atazanavir/ritonavir; AZT, azidothymidine; COR, crude OR; ddl, didanosine; EFV, efavirenz; LPV/r, lopinavir/ritonavir; NFV, nelfinavir; NVP, nevirapine; ref, reference; 3TC, lamivudine; TDF, tenofovir disoproxil fumarate; VL, viral load.

ART failure, suspected ART failure on initial VL, viral non-suppression, regimens 1d (azidothymidine (AZT)lamivudine (3TC)-efavirenz (EFV)), 1e (tenofovir disoproxil fumarate (TDF)-3TC-EFV), 2f (AZT-3TCatazanavir/ritonavir (ATV/r) ) and 2h (TDF-3TC-ATV/r), and second-line treatment (table 2).

In the multivariate analysis, patients who had immune recovery were less likely to be male (adjusted OR $(\mathrm{AOR})=0.50,95 \% \mathrm{CI} 0.45$ to $0.55, \mathrm{p}<0.001)$. Patients aged 20-34 (AOR $=0.33,95 \%$ CI 0.23 to $0.49, \mathrm{p}<0.001), 35-49$ (AOR $=0.30,95 \%$ CI 0.20 to $0.43, \mathrm{p}<0.001$ ) and older than 50 years old $(\mathrm{AOR}=0.26,95 \%$ CI 0.18 to $0.39, \mathrm{p}<0.001$ ) were less likely to have immunological recovery compared with patients aged $15-19$ years. Patients at WHO clinical stage III (AOR $=0.68,95 \%$ CI 0.48 to $0.98, p=0.036$ ) had less likelihood of immunological recovery than patients at WHO stage I. Patients who had immunological recovery also had fewer occurrences of suspected clinical ART failure $(\mathrm{OR}=0.13,95 \%$ CI 0.02 to $0.98, \mathrm{p}<0.05)$, suspected immunological ART failure (AOR=0.15, 95\% CI 0.04 to $0.49, \mathrm{p}<0.01)$ and suspected ART failure on initial VL (AOR $=0.43,95 \%$ CI 0.33 to $0.58, \mathrm{p}<0.001$ ), compared with the test reason of first VL. Similarly, immunological recovery occurred less in patients with non-suppressed VL $(\mathrm{AOR}=0.38,95 \%$ CI 0.33 to $0.42, \mathrm{p}<0.001)$ compared with virally suppressed patients. Likewise, immunological recovery occurred less in patients on regimen types $1 \mathrm{e}$ (AOR $=0.53,95 \%$ CI 0.48 to $0.59, \mathrm{p}<0.001), 2 \mathrm{f}(\mathrm{AOR}=0.29$, $95 \%$ CI 0.12 to $0.70, \mathrm{p}<0.01)$ and $2 \mathrm{~h}(\mathrm{AOR}=0.33,95 \%$ CI 0.19 to $0.57, \mathrm{p}<0.001$ ) as compared with $1 \mathrm{c}$ (table 3 ).

\section{DISCUSSION}

The aim of this study was to identify the determinants of immunological recovery following HAART in severely immunosuppressed HIV-infected adolescent and adult patients at enrolment in Northern Ethiopia. The study showed only $28.35 \%$ (95\% CI $27.45 \%$ to $29.26 \%$ ) had immunologically recovered $\left(\geq 500\right.$ cells $\left./ \mathrm{mm}^{3}\right)$ after receiving ART for at least 6 months. The adjusted analysis found that gender, age, WHO stage III, suspected treatment failure (clinical, immunological and virological), viral non-suppression, 1e (TDF3TC-EFV) regimen, 2f (AZT-3TC-ATV/r) regimen and $2 \mathrm{~h}$ (TDF-3TC-ATV/r) regimen were determinants of immunological recovery among patients with severe immunosuppression at enrolment.

Out of the 9687 patients with severe immunosuppression, $2746(28.35 \%, 95 \%$ CI $27.45 \%$ to $29.26 \%)$ had immunological recovery after receiving ART for at least 6 months. This finding is lower compared with a study conducted in Bahir Dar, Ethiopia where $30.8 \%$ of patients had CD4 count $\geq 500$ cells $/ \mathrm{mm}^{3}{ }^{32}$ Similarly, other studies have reported that $37.6 \%-59 \%$ of patients recovered immunologically. ${ }^{33}{ }^{34}$ Various research findings have also shown that baseline CD4 cell count $<200 / \mathrm{mm}^{3}$ when starting ART is a risk factor for poor immunological response. ${ }^{35-38}$ This might be due to poor thymic function following ART initiation in severely immunosuppressed patients.

This study revealed that male gender was strongly associated with immune recovery, where male patients were 0.50 times less likely to achieve immune recovery than female patients. There are other studies that indicated female patients have better immune recovery than male patients. ${ }^{1620} 39-43$ However, another research from Sub-Saharan countries indicated that gender was not associated with an increase in $\mathrm{CD} 4$ counts. ${ }^{44}$ The reported gender difference in CD4 cell count might be due to a sex hormone effect. ${ }^{45}$ This difference may be justified as male patients are poor with regard to health-seeking behaviour, leading to lower rates of HIV testing and acceptance of linkage to HIV care after a positive result. ${ }^{46}$

In this study, the age categories 20-34, 35-49, and 50 years and above were strongly associated with immune recovery, with these patients $0.33,0.30$ and 0.26 times less likely to achieve immune recovery, respectively, compared with the 15-19 years age category. There is also evidence showing that commencing ART at a younger age may be associated with an improved immunological response. ${ }^{38} 4748$ The EuroSIDA study also confirmed the inverse relationship between age and maximum CD4 cell response. Initiation of ART at a younger age may favour CD4 cell restoration due to a preserved thymic function. However, there are also other studies which suggest age has no significant association with increase in CD4 cell count. ${ }^{21}$ The variation among these studies might be due to differences in study design and time to follow-up for HAART.

This study revealed that WHO stage III was strongly associated with immune recovery, where patients at WHO stage III were 0.68 times less likely to achieve immune recovery than patients at WHO stage I. This evidence was also supported by a similar observation that patients in advanced HIV stage had poor immune recovery as compared with those in the early stages of the disease. ${ }^{48}$ A similar study from Tanzania reported that patients at WHO stage III and IV were more likely to achieve an inadequate immune recovery on receipt of ART as compared with those at WHO stage I and II. ${ }^{49}$ These 
Table 3 Multivariate analysis of variables associated with immunological recovery among severely immunosuppressed adolescent and adult patients in Northern Ethiopia, N=9687

\begin{tabular}{|c|c|c|c|}
\hline Variable & Category & AOR $(95 \% \mathrm{Cl})$ & $P$ value \\
\hline \multirow[t]{2}{*}{ Gender } & Female & 1 (ref) & \\
\hline & Male & 0.50 (0.45 to 0.55$)$ & $<0.001$ \\
\hline \multirow[t]{4}{*}{ Age category } & $15-19$ & 1 (ref) & \\
\hline & $20-34$ & 0.33 (0.23 to 0.49$)$ & $<0.001$ \\
\hline & $35-49$ & 0.30 (0.20 to 0.43$)$ & $<0.001$ \\
\hline & $50+$ & 0.26 (0.18 to 0.39$)$ & $<0.001$ \\
\hline \multirow[t]{4}{*}{ WHO stage } & I & 1 (ref) & \\
\hline & II & 0.90 (0.70 to 1.17$)$ & 0.451 \\
\hline & III & 0.68 (0.48 to 0.98$)$ & 0.036 \\
\hline & IV & 1.13 (0.87 to 1.46$)$ & 0.360 \\
\hline \multirow[t]{3}{*}{ Adherence } & Poor & 1 (ref) & \\
\hline & Fair & 0.62 (0.38 to 1.02$)$ & 0.061 \\
\hline & Good & 1.14 (0.75 to 1.72$)$ & 0.548 \\
\hline \multirow{6}{*}{$\begin{array}{l}\text { Viral test } \\
\text { reason }\end{array}$} & Routine first VL & 1 (ref) & \\
\hline & $\begin{array}{l}\text { Routine annual } \\
\text { VL }\end{array}$ & $1.02(0.92$ to 1.13$)$ & 0.710 \\
\hline & $\begin{array}{l}\text { Suspected } \\
\text { clinical ART } \\
\text { failure }\end{array}$ & 0.13 (0.02 to 0.98$)$ & 0.048 \\
\hline & $\begin{array}{l}\text { Suspected } \\
\text { immunological } \\
\text { ART failure }\end{array}$ & 0.15 (0.04 to 0.49$)$ & 0.002 \\
\hline & $\begin{array}{l}\text { Suspected ART } \\
\text { failure on initial } \\
\text { VL }\end{array}$ & 0.43 (0.33 to 0.58$)$ & $<0.001$ \\
\hline & $\begin{array}{l}\text { Not indicated in } \\
\text { the form }\end{array}$ & 0.88 (0.62 to 1.26$)$ & 0.510 \\
\hline \multirow{2}{*}{$\begin{array}{l}\text { Recent VL } \\
\text { status }\end{array}$} & Suppressed & 1 (ref) & \\
\hline & Non-suppressed & 0.38 (0.33 to 0.42$)$ & $<0.001$ \\
\hline \multirow[t]{9}{*}{ Drug regimen } & $\begin{array}{l}\text { 1c (AZT-3TC- } \\
\text { NVP) }\end{array}$ & 1 (ref) & \\
\hline & $\begin{array}{l}\text { 1d (AZT-3TC- } \\
\text { EFV) }\end{array}$ & 0.92 (0.79 to 1.08$)$ & 0.321 \\
\hline & $\begin{array}{l}\text { 1e (TDF-3TC- } \\
\text { EFV) }\end{array}$ & 0.53 (0.48 to 0.59$)$ & $<0.001$ \\
\hline & $\begin{array}{l}\text { 1f (TDF-3TC- } \\
\text { NVP) }\end{array}$ & 0.90 (0.77 to 1.04$)$ & 0.140 \\
\hline & $\begin{array}{l}1 \mathrm{~g}(\mathrm{ABC}-3 \mathrm{TC}- \\
\text { EFV) }\end{array}$ & 0.36 (0.03 to 4.02$)$ & 0.408 \\
\hline & $\begin{array}{l}\text { 1h (ABC-3TC- } \\
\text { NVP) }\end{array}$ & 0.71 (0.06 to 8.15$)$ & 0.783 \\
\hline & $\begin{array}{l}\text { 2a (ABC-ddl- } \\
\text { LPV/r), 2c (TDF- } \\
\text { ddl-LPV/r), 2d } \\
\text { (TDF-ddl-NFV) } \\
\text { and 2g (TDF- } \\
\text { 3TC-LPV/r) }\end{array}$ & 0.94 (0.17 to 5.33$)$ & 0.947 \\
\hline & $\begin{array}{l}2 f(A Z T-3 T C- \\
\text { ATV/r) }\end{array}$ & 0.29 (0.12 to 0.70$)$ & 0.006 \\
\hline & $\begin{array}{l}\text { 2h (TDF-3TC- } \\
\text { ATV/r) }\end{array}$ & 0.33 (0.19 to 0.57$)$ & $<0.001$ \\
\hline \multirow{2}{*}{$\begin{array}{l}\text { Service } \\
\text { provided in } \\
\text { a defence } \\
\text { facility }\end{array}$} & No & 1 (ref) & \\
\hline & Yes & 0.95 (0.72 to 1.26$)$ & 0.740 \\
\hline
\end{tabular}

Continued
Table 3 Continued

Variable Category $\quad$ AOR $(95 \% \mathrm{Cl}) \quad$ P value

ABC, abacavir; AOR, adjusted OR; ART, antiretroviral therapy; ATV/r, atazanavir/ritonavir; AZT, azidothymidine; ddl, didanosine; EFV, efavirenz; LPV/r, lopinavir/ritonavir; NFV, nelfinavir; NVP, nevirapine; ref, reference; 3TC, lamivudine; TDF, tenofovir disoproxil fumarate; VL, viral load.

findings suggest that patients at advanced HIV/AIDS clinical stages and with severe immune suppression need a much closer clinical follow-up to improve their immunological and clinical outcomes. In this study, about $90 \%$ of patients with $<200$ CD4 T cell count were classified under WHO stage I. This might be due to a wrong method of classifying patients according to WHO staging. Although the correlation of CD4 count and WHO staging is not perfect, patients with $<200$ CD4 T cells are more likely to have advanced HIV infection that may be classified into WHO stage III or IV. This indicates that there was an improper review and assessment of patients under the care of ART care providers. ${ }^{50}$

This study revealed that viral non-suppression was strongly associated with immune recovery, where virally nonsuppressed patients were 0.38 times less likely to achieve immune recovery than virally suppressed patients. There was strong evidence in Ghana of having CD4 count $<350$ cells/ $\mathrm{mm}^{3}$ after 6 months on ART and having plasma VL $>1000$ copies $/ \mathrm{mL} .{ }^{51}$ Other studies from Ethiopia, Nepal, Thailand and India reported that patients with HIV RNA level $\geq 1000$ copies/mL were more likely to experience immunological failure at ART follow-up as compared with those who had HIV RNA level $<1000$ copies/mL. ${ }^{31}$ 52-54 Another study has also shown that maintaining virological suppression results in a greater increase in CD4 cell count in the long term. ${ }^{55}$ This study has also supported that patients with suspected clinical ART failure, suspected immunological ART failure and suspected ART failure on initial VL were $0.13,0.15$ and 0.43 times less likely to achieve immunological recovery, respectively as compared to the test reason of initial VL. These findings agree with the knowledge that viral suppression leads to immune recovery. This is due to the fact that as viraemia increases, the depletion of $\mathrm{CD} 4$ cells increases.

This study showed that patients on regimens 1e (TDF3TC-EFV), 2f (AZT-3TC-ATV/r) and 2h (TDF-3TC-ATV/r) were $0.53,0.29$ and 0.33 times less likely to achieve immunological recovery, respectively, compared with the 1c (AZT-3TC-NVP) regimen. However, a study from Ethiopia showed that there was no significant association among the $3 \mathrm{TC}+\mathrm{d} 4 \mathrm{~T}+\mathrm{NVP}, 3 \mathrm{TC}+\mathrm{d} 4 \mathrm{~T}+\mathrm{EFV}, 3 \mathrm{TC}+\mathrm{AZT}+\mathrm{NVP}$ and 3TC+AZT+EFV drug regimens and CD4 count. ${ }^{56}$ Another study from Nepal reported that initiating ART using any one of the following ART regimens prevented treatment failure: 1c (AZT-3TC-NVP), 1d (AZT+3TC+EFV) and 1e $(\mathrm{TDF}+3 \mathrm{TC}+\mathrm{EFV}) .{ }^{57}$ This variation might be due to sample size variations or associations created by a random chance or other biological and unknown characteristics.

In summary, this study showed lower immunological recovery among immunosuppressed patients following HAART for at least 6 months. Being male, age older than 
19 years, WHO stage III, viral non-suppression, reasons for VL test (suspected clinical ART failure, suspected immunological ART failure and suspected ART failure on initial VL), and ART drug regimens $1 \mathrm{e}, 2 \mathrm{f}$ and $2 \mathrm{~h}$ predicted immunological failure. This study was specific to Tigray Region, North Ethiopia; however, the findings can be representative of Ethiopia and other LMICs.

The strength of the study is that it was done using routinely collected public health programme data which can reflect the outcome of the current ART management in severely immunosuppressed patients at enrolment. Additionally, this study was done on a relatively higher sample size, which can be generalised to regional and national levels using appropriate statistical analysis to present the findings. The study however is not without limitations. First, there were no data available when baseline and recent CD4 T cell count was conducted and hence the time when the immunological recovery had occurred is not known. Second, due to the nature of the secondary data, the analysis misses some important variables, such as the existence of coinfection, drug side effects during follow-up, body mass index and the grade of ART experience among HIV-infected patients.

\section{CONCLUSIONS}

Immunological recovery following HAART was low among severely immunosuppressed patients at enrolment to care. Gender, age, WHO stage III and viral suppression status were determinants of immunological recovery. Men and adolescents with severe immunosuppression should be identified as groups at higher risk for immunological failure. Therefore, a greater support and intensive counselling should be prioritised to adolescents, men and virally non-suppressed individuals in the Ethiopian healthcare system.

\section{Author affiliations}

${ }^{1}$ Public Health Research, Tigray Health Research Institute, Mekelle, Tigray, Ethiopia

${ }^{2}$ Tigray Health Research Institute, Mekelle, Tigray, Ethiopia

${ }^{3}$ Microbiology, Mekelle University College of Health Sciences, Mekelle, Tigray, Ethiopia

${ }^{4}$ Biostatistics School of Public Health, Mekelle University College of Health Sciences, Mekelle, Tigray, Ethiopia

Acknowledgements We would like to acknowledge the Tigray Health Research Institute (THRI) for providing the data for this study. We also wish to extend our gratitude to the THRI data clerks for their kind cooperation in providing the data required for this study.

Contributors AAD conceptualised and designed the study, and was involved in data analyses, acquisition of data, tabulating the data, interpretation of data, preparing the tables and figures, critically revising the manuscript, final review and drafting the initial manuscript. KMK, YWB, KFA, AGW, AAB, NMB, ABW and TWW were coauthors and contributed to the conception of the study, analyses, and revising and approval of the final manuscript. AAD had the primary responsibility for the final content and was involved in the final review. All authors read and approved the final manuscript.

Funding The authors have not declared a specific grant for this research from any funding agency in the public, commercial or not-for-profit sectors.

Map disclaimer The depiction of boundaries on the map(s) in this article do not imply the expression of any opinion whatsoever on the part of BMJ (or any member of its group) concerning the legal status of any country, territory, jurisdiction or area or of its authorities. The map(s) are provided without any warranty of any kind, either express or implied.
Competing interests None declared.

Patient consent for publication Obtained.

Ethics approval Ethical clearance and approval were obtained from the Tigray Health Research Institute (THRI) Institutional Review Board (IRB)/Ethical Review Committee (reference number THRI/00132/19). Permission to use the data was obtained from the Tigray Regional Health Bureau and THRI. The data were from a secondary database on HIV-infected patients for VL monitoring while on combination of antiretroviral treatment. All the baseline and recent CD4 counts were extracted from the database retrospectively, which were entered from the sample referral form. The data were not accessible by any other third party other than the study team. The data carry MRN personal identifiers. Informed consent was waived from the ethics committee.

Provenance and peer review Not commissioned; externally peer reviewed.

Data availability statement Data may be obtained from a third party and are not publicly available. The data that support the findings of this study are available from the Tigray Regional Health Bureau and THRI but restrictions apply to the availability of these data, which were used under licence for the current study and so are not publicly available. Data are however available from the authors upon reasonable request and with permission from the Tigray Regional Health Bureau and Institutional Review Board (IRB) of Tigray Health Research Institute via institutional. review.board.thri@gmail.com.

Open access This is an open access article distributed in accordance with the Creative Commons Attribution Non Commercial (CC BY-NC 4.0) license, which permits others to distribute, remix, adapt, build upon this work non-commercially, and license their derivative works on different terms, provided the original work is properly cited, appropriate credit is given, any changes made indicated, and the use is non-commercial. See: http://creativecommons.org/licenses/by-nc/4.0/.

\section{ORCID iDs}

Abraham Aregay Desta http://orcid.org/0000-0002-1505-7451

Tewolde Wubayehu Woldearegay http://orcid.org/0000-0001-7619-1112

\section{REFERENCES}

1 Vidya Vijayan KK, Karthigeyan KP, Tripathi SP, et al. Pathophysiology of CD4+ T-cell depletion in HIV-1 and HIV-2 infections. Front Immunol 2017;8:580.

2 Martin N, Sattentau Q. Cell-to-cell HIV-1 spread and its implications for immune evasion. Curr Opin HIV AIDS 2009;4:143-9.

3 Alexaki A, Liu Y, Wigdahl B. Cellular reservoirs of HIV-1 and their role in viral persistence. Curr HIV Res 2008;6:388-400.

4 Ford ES, Puronen CE, Sereti I. Immunopathogenesis of asymptomatic chronic HIV infection: the calm before the storm. Curr Opin HIV AIDS 2009;4:206-14.

5 Lange CG, Lederman MM. Immune reconstitution with antiretroviral therapies in chronic HIV-1 infection. J Antimicrob Chemother 2003;51:1-4

6 Kaufmann GR, Bloch M, Finlayson R, et al. The extent of HIV1-related immunodeficiency and age predict the long-term CD4 T lymphocyte response to potent antiretroviral therapy. AIDS 2002;16:359-67.

7 da Silva Escada RO, Velasque L, Ribeiro SR, et al. Mortality in patients with HIV-1 and tuberculosis co-infection in Rio de Janeiro, Brazil - associated factors and causes of death. BMC Infect Dis 2017; 17:373.

8 Autran B, Carcelain G, Li TS, et al. Positive effects of combined antiretroviral therapy on CD4+ T cell homeostasis and function in advanced HIV disease. Science 1997;277:112-6.

9 World Health Organisation. Consolidated guidelines on the use of antiretroviral drugs for treating and preventing HIV infection: recommendations for a public health approach. Geneva: World Health Organisation, 2013.

10 Palella FJ, Delaney KM, Moorman AC, et al. Declining morbidity and mortality among patients with advanced human immunodeficiency virus infection. HIV outpatient study investigators. N Engl J Med 1998;338:853-60.

11 Hammer SM, Squires KE, Hughes MD, et al. A controlled trial of two nucleoside analogues plus indinavir in persons with human immunodeficiency virus infection and CD4 cell counts of 200 per cubic millimeter or less. AIDS clinical trials Group 320 study Team. $N$ Engl J Med 1997;337:725-33.

12 UNAIDS. Global HIVIAIDS statistics. Fact sheets, 2017.

13 World Health Organisation. Guideline on when to start ART and on preexposure prophylaxis for HIV, 2015. 
14 World Health Organisation. Consolidated guidelines on the use of antiretroviral drugs for treating and preventing HIV infection: recommendations for a public health approach. 2nd ed. Geneva, Switzerland: World Health Organisation, 2016.

15 Kaufmann GR, Perrin L, Pantaleo G, et al. CD4 T-lymphocyte recovery in individuals with advanced HIV-1 infection receiving potent antiretroviral therapy for 4 years: the Swiss HIV cohort study. Arch Intern Med 2003;163:2187-95.

16 Kelley CF, Kitchen CMR, Hunt PW, et al. Incomplete peripheral CD4+ cell count restoration in HIV-infected patients receiving long-term antiretroviral treatment. Clin Infect Dis 2009;48:787-94.

17 Egger M, May M, Chêne G, et al. Prognosis of HIV-1-infected patients starting highly active antiretroviral therapy: a collaborative analysis of prospective studies. Lancet 2002;360:119-29.

18 May M, Sterne JAC, Sabin C, et al. Prognosis of HIV-1-infected patients up to 5 years after initiation of HAART: collaborative analysis of prospective studies. AIDS 2007;21:1185-97.

19 Sterling TR, Chaisson RE, Keruly J, et al. Improved outcomes with early initiation of HAART among HIV-infected patients who achieve durable virological suppression: longer follow-up of an observational cohort. J Infect 2003;188:1659-65.

20 Moore RD, Keruly JC. CD4+ cell count 6 years after commencement of highly active antiretroviral therapy in persons with sustained virologic suppression. Clin Infect Dis 2007;44:441-6.

21 Smith CJ, Sabin CA, Youle MS, et al. Factors influencing increases in CD4 cell counts of HIV-positive persons receiving long-term highly active antiretroviral therapy. J Infect Dis 2004;190:1860-8.

22 Hoenigl M, Chaillon A, Moore DJ, et al. Rapid HIV viral load suppression in those initiating antiretroviral therapy at first visit after HIV diagnosis. Sci Rep 2016;6:32947.

23 Montarroyos UR, Miranda-Filho DB, César CC, et al. Factors related to changes in CD4+ T-cell counts over time in patients living with HIV/AIDS: a multilevel analysis. PLoS One 2014;9:e84276.

24 Florence $\mathrm{E}$, Lundgren J, Dreezen $\mathrm{C}$, et al. Factors associated with a reduced CD4 lymphocyte count response to HAART despite full viral suppression in the EuroSIDA study. HIV Med 2003;4:255-62.

25 Singini I, Campbell TB, Smeaton LM, et al. Predictors of late virologic failure after initial successful suppression of HIV replication on efavirenz-based antiretroviral therapy. HIV Clin Trials 2016;17:173-80.

26 Rohr JK, Ive P, Horsburgh CR, et al. Developing a predictive risk model for first-line antiretroviral therapy failure in South Africa. J Int AIDS Soc 2016;19:20987.

27 UNAIDS. UNAIDS 90-90-90: an ambitious treatment target to help end the AIDS epidemic Geneva, Switzerland. Geneva, Switzerland: UNAIDS, 2014

28 Desta AA, Wubayehu Woldearegay T, Berhe AA, et al. Immunological recovery, failure and factors associated with $\mathrm{CD}-4 \mathrm{~T}$-cells progression over time, among adolescents and adults living with HIV on Antiretroviral Therapy in Northern Ethiopia: a retrospective cross sectional study. PLoS One 2019;14:e0226293.

29 Desta AA, Woldearegay TW, Futwi N, et al. HIV virological nonsuppression and factors associated with non-suppression among adolescents and adults on antiretroviral therapy in Northern Ethiopia: a retrospective study. BMC Infect Dis 2020;20:4

30 Hailu GG, Hagos DG, Hagos AK, et al. Virological and immunological failure of HAART and associated risk factors among adults and adolescents in the Tigray region of northern Ethiopia. PLoS One 2018;13:e0196259.

31 Wikipedia, the free encyclopedia. Available: https://en.wikipedia.org/ wiki/Tigray_Region [Accessed Sep 2019].

32 Gezie LD, Gelaye KA, Worku AG, et al. Time to immunologic recovery and determinant factors among adults who initiated ART in Felege Hiwot referral hospital, Northwest Ethiopia. BMC Res Notes 2017; 10:277

33 Gezie LD. Predictors of CD4 count over time among HIV patients initiated ART in Felege Hiwot referral hospital, Northwest Ethiopia: multilevel analysis. BMC Res Notes 2016;9:377.

$34 \mathrm{Kim} \mathrm{K-H}$, Yi J, Lee SH. The CD4 slope can be a predictor of immunologic recovery in advanced HIV patients: a case-control study. Korean J Intern Med 2015;30:705-13.

35 Corbeau P, Reynes J. Immune reconstitution under antiretroviral therapy: the new challenge in HIV-1 infection. Blood 2011;117:5582-90.

36 Guihot A, Bourgarit A, Carcelain G, et al. Immune reconstitution after a decade of combined antiretroviral therapies for human immunodeficiency virus. Trends Immunol $2011 ; 32: 131-7$
37 Tsukamoto H, Clise-Dwyer K, Huston GE, et al. Age-associated increase in lifespan of naive CD4 T cells contributes to T-cell homeostasis but facilitates development of functional defects. Proc Natl Acad Sci U S A 2009;106:18333-8.

38 Rajasuriar R, Gouillou M, Spelman T, et al. Clinical predictors of immune reconstitution following combination antiretroviral therapy in patients from the Australian HIV observational database. PLoS One 2011;6:e20713.

39 Anude CJ, Eze E, Onyegbutulem HC, et al. Immuno-virologic outcomes and immuno-virologic discordance among adults alive and on anti-retroviral therapy at 12 months in Nigeria. BMC Infect Dis 2013;13:113.

40 Shastri S, Boregowda $\mathrm{PH}$, Rewari BB, et al. Scaling up antiretroviral treatment services in Karnataka, India: impact on CD4 counts of HIVinfected people. PLoS One 2013;8:e72188.

41 Malaza A, Mossong J, Bärnighausen T, et al. Population-based CD4 counts in a rural area in South Africa with high HIV prevalence and high antiretroviral treatment coverage. PLoS One 2013;8:e70126.

42 Nanzigu S, Kiguba R, Kabanda J, et al. Poor immunological recovery among severely immunosuppressed antiretroviral therapy-naïve Ugandans. HIV AIDS 2013;5:309-19.

43 Gandhi RT, Spritzler J, Chan E, et al. Effect of baseline- and treatment-related factors on immunologic recovery after initiation of antiretroviral therapy in HIV-1-positive subjects: results from ACTG 384. J Acquir Immune Defic Syndr 2006;42:426-34.

44 Lawn SD, Myer L, Bekker L-G, et al. CD4 cell count recovery among HIV-infected patients with very advanced immunodeficiency commencing antiretroviral treatment in sub-Saharan Africa. BMC Infect Dis 2006;6:59.

45 Maini MK, Gilson RJ, Chavda N, et al. Reference ranges and sources of variability of CD4 counts in HIV-seronegative women and men. Genitourin Med 1996;72:27-31.

46 Galdas PM, Cheater F, Marshall P. Men and health help-seeking behaviour: literature review. J Adv Nurs 2005;49:616-23.

47 Viard JP, Mocroft A, Chiesi A, et al. Influence of age on CD4 cell recovery in human immunodeficiency virus-infected patients receiving highly active antiretroviral therapy: evidence from the EuroSIDA study. J Infect Dis 2001;183:1290-4.

48 Kaufmann GR, Bloch M, Finlayson R, et al. The extent of HIV1-related immunodeficiency and age predict the long-term CD4 $\mathrm{T}$ lymphocyte response to potent antiretroviral therapy. AIDS 2002;16:359-67.

49 Gunda DW, Kilonzo SB, Kamugisha E, et al. Prevalence and risk factors of poor immune recovery among adult HIV patients attending care and treatment centre in northwestern Tanzania following the use of highly active antiretroviral therapy: a retrospective study. BMC Res Notes 2017;10:197.

50 Desta AA, Mehari KK, Berhe AA, et al. Prediction of CD4 Tlymphocyte count using who clinical staging among ART-Naïve HIVinfected adolescents and adults in northern Ethiopia: a retrospective study. AIDS Res Treat Hindawi 2020:2163486.

51 Obiri-Yeboah D, Pappoe F, Baidoo I, et al. Immunologic and virological response to ART among HIV infected individuals at a tertiary hospital in Ghana. BMC Infect Dis 2018;18:230.

52 Ojha CR, Shakya G, Dumre SP. Virological and immunological status of the people living with HIV/AIDS undergoing ART treatment in Nepal. Biomed Res Int 2016;2016:1-7.

53 Puthanakit T, Kerr S, Ananworanich J, et al. Pattern and predictors of immunologic recovery in human immunodeficiency virus-infected children receiving non-nucleoside reverse transcriptase inhibitor-based highly active antiretroviral therapy. Pediatr Infect Dis J 2009;28:488-92.

54 Raja K, Chandrasekar C, Krishnarajasekhar OR, et al. Predicting virological failure with immunological criteria in first line art patients in a resource poor setting. World J AIDS 2014;04:413-21.

55 Smith SR, Rublein JC, Marcus C, et al. A medication selfmanagement program to improve adherence to HIV therapy regimens. Patient Educ Couns 2003;50:187-99.

56 Mulu A, Liebert UG, Maier M. Virological efficacy and immunological recovery among Ethiopian HIV-1 infected adults and children. BMC Infect Dis 2014;14:28.

57 Ojha CR, Shakya G, Dumre SP. Virological and immunological status of the people living with HIV/AIDS undergoing art treatment in Nepal. Biomed Res Int 2016;2016:1-7. 